\author{
Kuznetsov M., \\ Kharlampidi D., \\ Tarasova V.
}

\title{
EXERGY ANALYSIS OF A COGENERATION SYSTEM FOR UTILIZATION OF WASTE HEAT OF INDUSTRIAL ENTERPRISES
}

Об’єктом дослідження є енергетичні процеси, що відбуваються в когенераційній системі утилізацї скидної теплоти промпідприємств у складі паротурбінної установки і абсорбційної теплонасосної установки. Одним з найбільш проблемних місць в ході розробки і проектування таких систем є те, що тепловий розрахунок абсорбційних теплонасосних установок в цілому являє собою досить важку задачу. Це пов'язано з наявністю кількох взаємозалежних теплообмінних апаратів $i$ складності термодинамічних $і$ масообмінних процесів, що протікають в них. В ході дослідження використовувалися сучасні методи аналізу термодинамічних систем, що засновані на застосуванні теоретичного апарату технічної термодинаміки $і$ теорії теплоi масопереносу. На основі математичного моделювання тепло- і масообмінних процесів для даної когенераційної системи побудовано програмний комплекс розрахунку ї термодинамічних і ексергетичних характеристик з метою проведення чисельних досліджень показників ї енергетичної ефективності. Отримано база даних для розрахунку теплофізичних властивостей водоаміачного розчину з урахуванням зміни його концентрації для ідентифікації параметрів стану розчину в вузлових точках чиклів. На основі чисельного експерименту проведено аналіз енергетичних і ексергетичних показників системи при варіюванні 4-х чинників:

1) температури конденсацї відпрацьованої водяної пари в паротурбінній установці;

2) температури гріючої технологічної води на вході в парогенератор паротурбінної установки;

3) температури зворотної мережевої води на вході в тепловий насос;

4) масової витрати мережевої води.

Отримано узагальнене регресійне рівняння функціонального взаємозв'язку ексергетичних ККД елементів когенераційної системи і всієї системи в цілому. Проаналізовано коефіщієнти впливу ексергетичних ККД елементів на термодинамічну досконалість всієї системи. Завдяки методу ексергетичного аналізу, що використовується в дослідженні, забезпечується можливість виявити природу зовнішніх і внутрішніх втрат як по циклах в цілому, так і по окремих елементах розглянутої когенераційної системи. А також намітити шляхи поліпшення їі схеми і конструкцї.

Ключові слова: ексергетичний аналіз, паротурбінна установка, абсорбційна теплонасосна установка, утилізація скидної теплоти.

Received date: 11.06.2019

Accepted date: 02.07.2019

Published date: 31.10 .2019
Copyright (C) 2019, Kuznetsov M., Kharlampidi D., Tarasova V. This is an open access article under the CC BY license (http://creativecommons.org/licenses/by/4.0)

\section{Introduction}

Solving issues of rational use of expensive and scarce fossil fuels in the generation of heat and electricity is an urgent problem for the energy wasteful economy of Ukraine.

Reducing the consumption of fossil fuels can be achieved through widespread use at industrial enterprises of the secondary energy resources (SER) generated by them. SER is the energy potential of products, waste, by-products and intermediate products generated in process units, which is not used in the main process. But it can be partially or fully involved in the energy supply of both SER source facilities and other consumers. Accordingly, the following are attributed to thermal SER:

- physical heat of exhaust gases of technological units;

- physical heat of the main and by-products;

- heat of the working fluid of the cooling systems

of the units;

- thermal waste from chemical enterprises;
- heat of hot water and steam spent in units;

- heat waste of thermal power stations and others [1, 2].

If high-potential SERs are widely used in various industries and efficient technologies and assemblies have been developed for this, then low-potential SERs are not utilized on a sufficient scale. Although they occupy about half of secondary energy resources in volume [1].

The effective use of low-grade heat of waste liquids and gases is associated with the creation of modern heatrecovery equipment that allows not only to reduce fuel consumption by an industrial enterprise, but also to reduce thermal pollution of the environment.

Therefore, it is relevant to research the effectiveness of introducing technical means in industry for saving organic fuel by attracting large amounts of waste heat generated by them into the energy balance of industrial enterprises.

Deep utilization of the heat of industrial process waste water can be implemented in the cogeneration system consisting of a steam turbine plant (STP) and an absorption heat pump (AHP). 


\section{The object of research and its technological audit}

The object of research is the energy processes occurring in the cogeneration system for the utilization of waste heat of industrial enterprises, consisting of a steam turbine plant and an absorption heat pump.

The cogeneration heat recovery system (Fig. 1) includes a water-ammonia absorption heat pump and a steam turbine plant where water is the working fluid. The use of a water-ammonia solution as an AHP working fluid is caused, firstly, by a sufficiently wide temperature range, which is important for reversible multi-purpose units, and, secondly, by the relatively low cost and non-deficiency of components. In addition, ammonia is one of the first among the safe, in terms of the impact on the ozone layer and global warming, natural refrigerants for use in thermotransformers with a capacity of more than $20 \mathrm{~kW}$ [3].

A steam turbine plant consists of a steam generator, a turbine with an electric generator and a feed pump. The composition of the absorption heat pump includes: a generator, a reflux condenser, a condenser, an absorber, a strong solution pump, and two throttle valves. Condenserevaporator is a common element that combines both units. For a steam turbine plant, it acts as a condenser, and for a heat pump unit it serves as an evaporator.
Cogeneration heat recovery system works as follows. Heating process water with a temperature of $175-215^{\circ} \mathrm{C}$ enters the steam generator of the steam turbine plant, where due to its heat the production of saturated water steam is ensured. The thermal energy of the steam is converted into mechanical energy of rotation of the turbine shaft, on which an electric generator that generates electricity is installed. After the turbine, the spent steam with a temperature of $30-45{ }^{\circ} \mathrm{C}$ is condensed in the condenser-evaporator and the condensate is pumped to the steam generator by the feed pump.

The heating process water after the steam generator with a temperature of $130-160{ }^{\circ} \mathrm{C}$ is sent to the heat pump generator, where it is cooled to $70-80{ }^{\circ} \mathrm{C}$, giving up heat to the water-ammonia solution, and is removed from the system. In the generator, a strong water-ammonia solution boils and its steam enters the reflux condenser, where as a result of a decrease in its temperature due to the supply of part of the reverse delivery water with a temperature of $30-40{ }^{\circ} \mathrm{C}$, its partial condensation occurs. The resulting condensate (reflux) is taken back to the generator, and the remaining steam of higher concentration is sent to the heat pump condenser, where it condenses at a temperature of $40-50{ }^{\circ} \mathrm{C}$ due to the supply of the rest of the reverse delivery water. Delivery water is heated in a condenser and reflux condenser to $60-65{ }^{\circ} \mathrm{C}$.

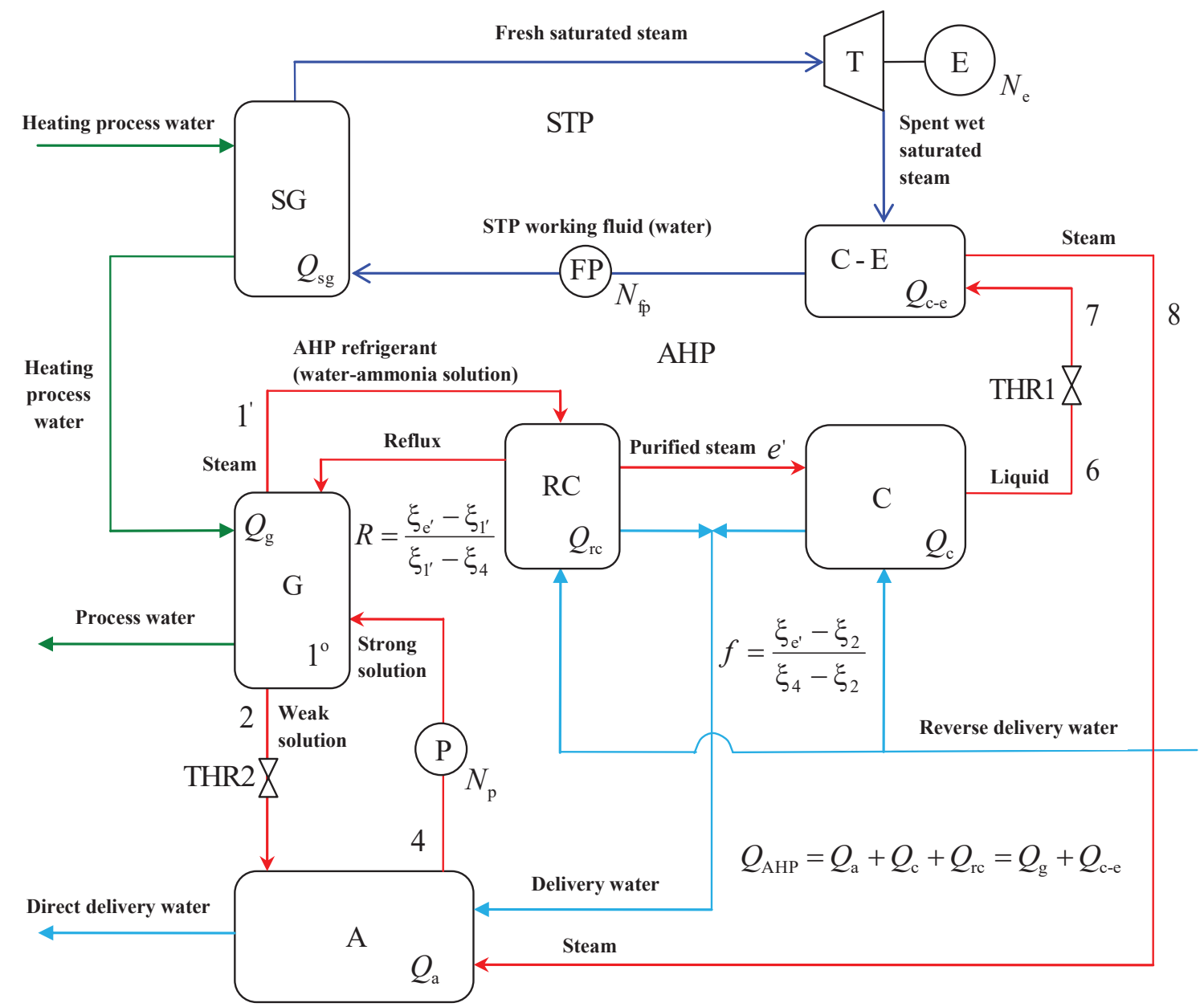

Fig. 1. Cogeneration system consisting of a steam turbine plant and an absorption heat pump:

SG - steam generator; STP - steam turbine plant; FP - feed pump; T - turbine; E - electric generator; C-E - condenser-evaporator; AHP - absorption heat pump; THR - throttle valve; G - generator; RC - reflux condenser; $\mathrm{C}$ - condenser; P - strong solution pump; A - absorber 
The liquid obtained in the heat pump condenser is throttled in the THR-1 throttle valve, and at a temperature of $15-30{ }^{\circ} \mathrm{C}$ the steam-liquid mixture is sent to the condenser-evaporator, where the liquid phase of the solution is evaporated. The resulting steam with a temperature of $25-40{ }^{\circ} \mathrm{C}$ enters the absorber, where a weak water-ammonia solution is also supplied from the generator through the THR-2 throttle valve. In the absorber, steam is absorbed by a weak solution, as a result of which the concentration of the solution rises, and a strong water-ammonia solution is pumped to the generator. The absorption process is accompanied by the release of heat, due to which the temperature of direct delivery water at the outlet of the absorber reaches $90{ }^{\circ} \mathrm{C}$.

One of the most problematic places during the development and design of such systems is that the thermal calculation of absorption heat pumps as a whole is a rather difficult task. This is due to the presence of several interconnected heat exchangers and the complexity of the thermodynamic and mass transfer processes occurring in them. It is possible to outline ways to improve the scheme and design of the considered cogeneration system in order to increase its energy efficiency using the method of exergy analysis, which allows to identify the nature of external and internal losses both in cycles in general and in individual elements of the system.

\section{The aim and objectives of research}

The aim of research is analysis of the indicators of energy and exergy efficiency of the cogeneration system for utilization of waste heat of industrial enterprises to find ways to increase the degree of its thermodynamic perfection.

To achieve this aim, it is necessary to complete the following tasks:

1. Based on mathematical modeling of heat and mass transfer processes, build a software package for calculating the thermodynamic and exergy characteristics of the cogeneration system under consideration.

2. Conduct a numerical experiment to predict the operating modes of the cogeneration system, taking into account the influence of the parameters of an external heat source, delivery water and spent water steam at the turbine outlet.

3. To analyze the functional relationship of exergy efficiency of the elements of the cogeneration system and the entire system as a whole to determine the most influential elements of the system while improving its scheme and design.

\section{Research of existing solutions of the problem}

The main directions for solving the problem of efficient use of low-grade waste heat of industrial enterprises are related to scientific research on the creation of modern heat-recovery equipment, which allows not only to reduce fuel consumption by an industrial enterprise, but also to reduce thermal pollution of the environment.

The work [4] explores the issues of utilization of waste heat of technological processes of industrial enterprises through the introduction of turbines on low-boiling fluids. In these units, the so-called organic Rankine cycle (ORC) is implemented and secondary energy resources having a temperature of $80-600{ }^{\circ} \mathrm{C}$ (cooling water, hot air from technological processes, etc.) are utilized. For two heat sources of small potential of a metallurgical enterprise with a full production cycle, the main characteristics of the turbines using working fluids R-600 and R-134a for different rotor speeds are calculated. The estimation of the electric power received during the implementation of the ORC circuit is carried out. An experimental study of the use of the Rankine organic cycle for the utilization of low-grade waste heat in the ceramic industry is carried out in [5]. Based on the obtained experimental data, a model of a heat recovery system is developed that allows predicting the net generation of electric energy by the system during the year of operation and quantifying the energy and environmental benefits of the project. It should be noted that the main disadvantage of heat recovery schemes focused only on the generation of electricity is the low utilization of the heat of process water.

In [6], the efficiency of using the system as a part of vapor-compression and absorption heat pumps for utilization of waste heat of a wide temperature range is analyzed. The authors of [7] conduct a study on the utilization of the waste heat of the condensers of refrigerators using water-ammonia absorption heat pumps. As a result, the efficiency of the combined system increased by $10.5 \%$. With an increase in the cooling load on the evaporator, the performance of the combined cooling cycle increases with an increase in the condenser heat output. However, when conducting these studies, fixed concentrations of strong and weak solutions are taken. This does not allow taking into account the effect of changes in the concentration of water-ammonia solution at the nodal points of the cycle when the load on the system changes and reduces the accuracy of the calculations.

In [8], a system for utilizing the waste heat of ammonia refrigeration machines of an industrial enterprise using a heat pump operating on a transcritical $\mathrm{CO}_{2}$ cycle is studied. The heat produced in the heat pump with a temperature of $70{ }^{\circ} \mathrm{C}$ is used for preheating the boiler feed water and thereby reduces energy consumption by the enterprise. The total fuel costs of the enterprise were reduced by $45.7 \%$, and the $\mathrm{CO}_{2}$ emission into the atmosphere is reduced by $33.8 \%$. However, the cost of $\mathrm{CO}_{2}$-based heat exchange equipment is extremely high because it is operated under significantly higher pressure compared to freon-based heat exchangers.

The authors of [9] show the possibility of using heat pipes to utilize the waste heat of coke and metallurgical enterprises. A flue gas recovery system based on an eccentric radial heat pipe is developed that allows the production of saturated steam as an additional product. By optimizing the location and structure of the system, it was possible to produce 0.19 GJ of saturated water steam per tonne of coke, while the system consumed only $1.29 \mathrm{~kW} / \mathrm{t}$ of electricity for its own needs. The disadvantage of using heat pipes is that they have a limited effective range of use. The choice of pipe material, its size and working fluid affects the optimal temperature range of its application, beyond which leads to a significant decrease in its effectiveness. In [10], studies of the efficiency of electricity production through the use of waste heat of an industrial enterprise using a combination of heat pipes and thermoelectric generators are presented. A description of laboratory studies with the aim of increasing the efficiency of the system is given. The advantage of thermoelectric generators is that they are compact and do not have moving parts. However, at the moment they are characterized by relatively high cost and low efficiency (5-8\%). 
In [11], a thermodynamic analysis of a thermophotovoltaic system for electricity production is carried out. The purpose of the analysis is studying the energy and exergy efficiency of the system in the utilization of waste heat from ferrous metallurgy enterprises. The system provides roundthe-clock power generation during continuous steelmaking processes. However, the disadvantage of photothermal cells is the currently low efficiency of thermal cells (about 4-5\%) and shortened service life due to heating during operation.

The possibility of using a heat pump instead of a cooling tower to lower the temperature and recover the waste heat of circulating cooling water in the hot stamping process cycle is considered in [12]. A thermodynamic analysis of the system is carried out, which shows the possibility of saving up to $180.29 \mathrm{~kg} / \mathrm{h}$ of coal while ensuring the specified parameters of the technological cycle and producing $15.82 \mathrm{t} / \mathrm{h}$ of hot water with a temperature of $60{ }^{\circ} \mathrm{C}$ for production needs and washing staff. The possibility of utilizing the heat of the cooling circulating water of a steam turbine plant using a vapor-compression heat pump is studied in [13]. The heat pump evaporator is built into the turbine condenser, which makes it possible to improve vacuum and increase electric power generation. As the authors themselves note, with an increase in the condensation temperature of the refrigerant vapor with an increase in the quality of the produced heat energy supplied to consumers, the efficiency of the vapor-compression heat pump decreases. The electric power consumed by the compressor, while growing and may exceed the additional generation of electricity.

Thus, the results of the analysis allow to conclude that studies to improve the energy efficiency of using cogeneration systems built using absorption heat pump systems for utilizing the waste heat of enterprises are promising. Heat-using absorption heat pumps practically do not consume electricity for their own needs and can be effectively used in combination with a steam turbine plant for the joint generation of heat and electricity.

\section{Methods of research}

Based on mathematical modeling of heat and mass transfer processes for the considered cogeneration heat recovery system, a software complex for calculating its thermodynamic and exergy characteristics has been constructed, the block diagram of which is shown in Fig. 2.

As the initial data for the calculation are accepted:

- required mass flow rate of heated delivery water $G_{d w}$;

- delivery water temperature at the inlet and outlet of the AHP, respectively $T_{d w 1}$ and $T_{d w 2}$;

- temperature of the heating process water at the inlet

to the STP steam generator $T_{p \text { w.sg } 1}$;

- condensation temperature of the spent water steam in the condenser-evaporator $T_{\text {C.STP }}$;

- temperature of water steam at the inlet to the turbine $T_{\text {we.t }}$;

- temperature differences of the heat transfer fluids on the cold and hot sides of the AHP condenser, respectively $\Delta T_{c . c}$ and $\Delta T_{c . h}$;

- temperature differences of the heat transfer fluids on the cold and hot sides of the condenser-evaporator, respectively $\Delta T_{c-e . c}$ and $\Delta T_{c-e . h}$;

- temperature difference of the heat transfer fluids on the cold side of the absorber $\Delta T_{a . c}$ and the hot side of the generator $\Delta T_{g . h}$.

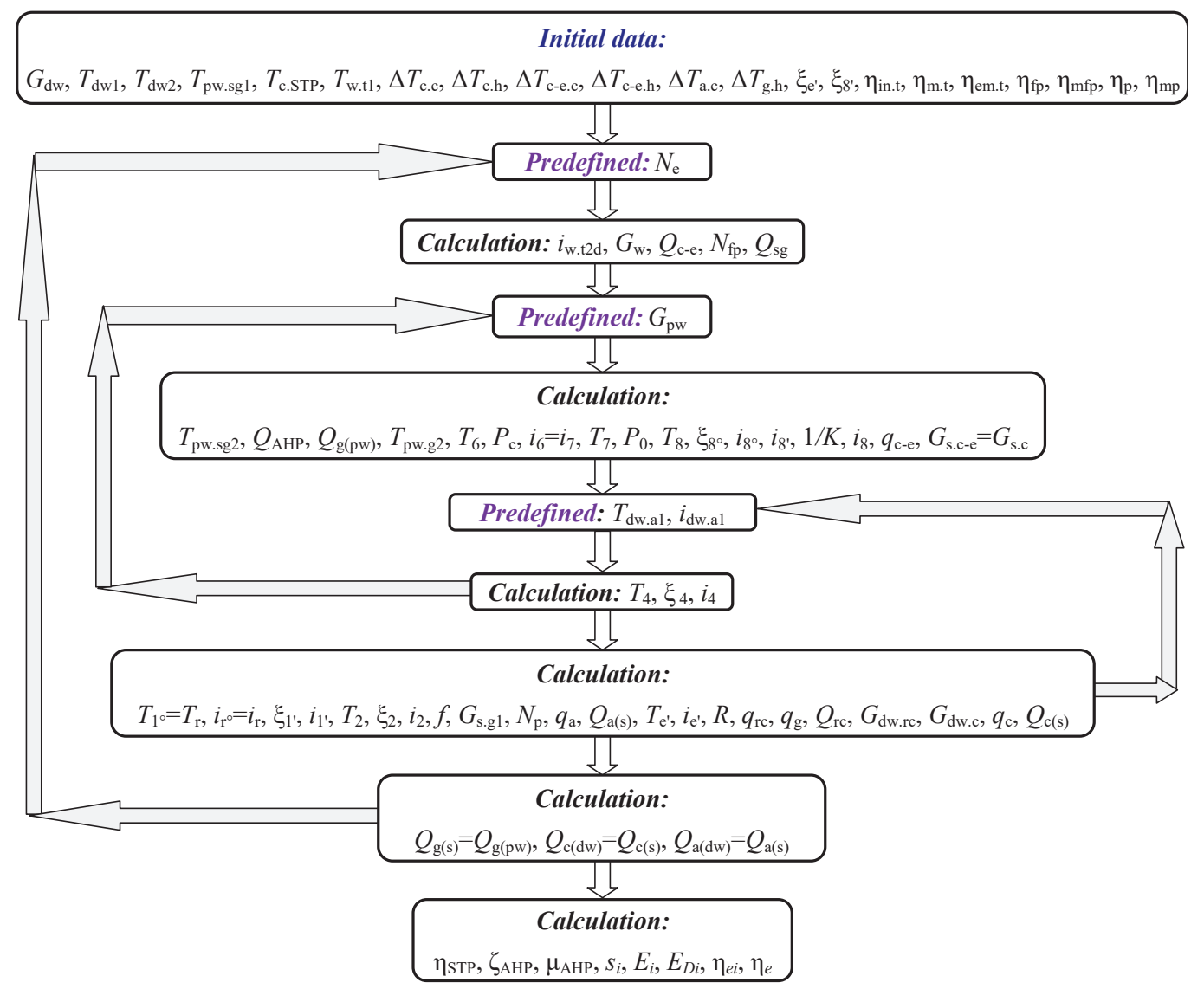

Fig. 2. The block diagram of the calculation of the cogeneration heat recovery system 
The concentration of the purified solution steam at the outlet of the reflux condenser $\xi_{e^{\prime}}$ and the saturated steam of solution at the end of the boiling process in the condenserevaporator $\xi_{8^{\prime}}$ are also set. In addition, the internal relative $\eta_{\text {in.t }}$, mechanical $\eta_{m . t}$ and electromechanical $\eta_{\text {em.t }}$ efficiency of the turbine-electric generating unit of the STP, the efficiency of the pumps $\eta_{f p}, \eta_{p}$ and their electric motors $\eta_{m f p}$, $\eta_{m p}$ should be known.

To identify the parameters of the state of the working fluid at the nodal points of the cycles of the absorption heat pump, a database has been obtained for calculating the thermophysical properties (enthalpy $i$, entropy $s$ ) of the water-ammonia solution taking into account changes in its concentration $\xi$.

The subsequent calculation is made by asking preliminary values of the electric power $N_{e}$ generated by the steam turbine plant, the required mass flow rate of the heating process water $G_{p w}$, and the delivery water parameters at the inlet to the heat pump absorber $T_{d w a}, i_{d w . a 1}$. These values during the calculation are specified as a result of three iteration cycles (Fig. 2) until the energy balances for all working fluids and heat transfer fluids in all heat exchangers of the system are reached.

The following system parameters are calculated based on the known dependences presented in [14-16]:

- the actual enthalpy of the spent wet saturated water steam at the outlet of the turbine:

$$
i_{w . t 2 d}=i_{w . t 1}-\eta_{i n . t}\left(i_{w . t 1}-i_{w . t 2 t}\right),
$$

where $i_{w . t 1}$ - enthalpy of water steam at the entrance to the turbine; $i_{\text {w. } t 2 t}$ - theoretical enthalpy of spent wet saturated water steam at the outlet of the turbine;

- mass flow rate of the working fluid (water) in the steam turbine plant:

$$
G_{w}=\frac{N_{e}}{\left(i_{w . t 1}-i_{w . t 2 d}\right) \eta_{e m . t}} ;
$$

- heating capacity of the condenser-evaporator:

$$
Q_{c-e}=G_{w}\left(i_{w . t 2 d}-i_{w \cdot c-c 2}\right),
$$

where $i_{\text {wec }-22}-$ the enthalpy of water at the outlet of the condenser-evaporator;

- electric power of the feed pump:

$$
N_{f p}=\frac{v_{w . f p} G_{w}\left(P_{w . t 1}-P_{w . t 2}\right)}{\eta_{f p} \eta_{m f p}},
$$

where $v_{z e . f p}$ - specific volume of water at the inlet to the feed pump; $P_{\text {zo.t1 }}, P_{\text {zo.t2 } 2}$ - respectively the pressure of water steam at the inlet and outlet of the turbine;

- heat output of the STP steam generator:

$$
Q_{s g}=Q_{c-e}+\frac{N_{e}}{\eta_{e m . t}}
$$

- the temperature of the heating process water at the outlet of the STP steam generator $T_{p w . s g 2}$, determined by the corresponding enthalpy:

$$
i_{p w . s g 2}=i_{p w . s g 1}-\frac{Q_{s g}}{G_{p w}},
$$

where $i_{\text {peess } 1}$ - the enthalpy of heating process water at the entrance to the STP steam generator;
- required heat output of $\mathrm{AHP}$ :

$Q_{A H P}=G_{d w}\left(i_{d w 2}-i_{d w 1}\right)$,

where $i_{d w 2}, i_{d w 1}$ - the enthalpy of delivery water at the inlet and outlet of the AHP, respectively;

- thermal power supplied to the generator by heating process water:

$Q_{g(p w)}=Q_{A H P}-Q_{c-e} ;$

- temperature of the heating process water at the outlet of the generator $T_{p w . g 2}$, determined by the corresponding enthalpy:

$i_{p w . g 2}=i_{p w . s g 2}-\frac{Q_{g(p w)}}{G_{p w}} ;$

- the lowest condensation temperature of the solution in the AHP condenser:

$T_{6}=T_{d \omega 1}+\Delta T_{c . c} ;$

- pressure in the condenser, generator and reflux condenser $P_{c}$, which is taken according to thermodynamic tables for pure ammonia [17] at $T_{6}$;

- the enthalpy of the liquid phase of the water-ammonia solution upon exiting the AHP condenser $i_{6}$, which is determined by the known values of $P_{c}, T_{6}$ and $\xi_{6}=\xi_{e^{\prime}}$; - the lowest boiling point of the steam-liquid mixture of the solution in the condenser-evaporator:

$T_{7}=T_{c . S T P}-\Delta T_{c-e . c}$

- enthalpy of wet steam of the solution at the beginning of boiling in a condenser-evaporator $i_{7}=i_{6}$;

- pressure in the condenser-evaporator and absorber $P_{0}$, which corresponds to $T_{7}$ and $\xi_{7}=\xi_{6}=\xi_{e^{\prime}}$;

- the highest boiling point of the steam-liquid mixture of the solution in the condenser-evaporator:

$T_{8}=T_{c . S T P}-\Delta T_{\text {c-e.h }} ;$

- concentration of the liquid phase of the solution in equilibrium with steam at the end of boiling in a condenser-evaporator $\xi_{8^{\circ}}$, determined by the known values of $P_{0}$ and $T_{8}$;

- enthalpy of the liquid phase of the solution in equilibrium with steam at the end of boiling in the condenserevaporator $i_{8^{\circ}}$, determined by $P_{0}, T_{8}$ and $\xi_{8^{\circ}}$;

- enthalpy of saturated steam of the solution at the end of boiling in the condenser-evaporator $i_{8^{\prime}}$, determined by the values of $P_{0}, T_{8}$ and $\xi_{8}$;

- tangent of the angle of inclination of the isotherm in the field of wet steam:

$\frac{1}{K}=\frac{i_{8^{\prime}}-i_{8^{\circ}}}{\xi_{8^{\prime}}-\xi_{8^{\circ}}} ;$

- enthalpy of wet steam of solution at the outlet of the evaporator:

$i_{8}=i_{8^{\prime}}-\frac{1}{K}\left(\xi_{8^{\prime}}-\xi_{e^{\prime}}\right)$ 
- specific heat load of the condenser-evaporator:

$q_{c-e}=i_{8}-i_{7}$

- mass flow rate of the water-ammonia solution in the condenser-evaporator and, accordingly, in the AHP condenser:

$G_{s . c-e}=G_{s . c}=\frac{Q_{c-e}}{q_{c-e}} ;$

- the lowest temperature of a strong water-ammonia solution during absorption in the absorber:

$T_{4}=T_{d w . a 1}+\Delta T_{a . c}$

- concentration of a strong water-ammonia solution after the absorber $\xi_{4}$, determined by the known values of $P_{0}$ and $T_{4}$;

- enthalpy of a strong water-ammonia solution after the $i_{4}$ absorber, determined by the values of $P_{0}, T_{4}$ and $\xi_{4}$.

After that, taking into account the economically reasonable temperature difference of the heat transfer fluids on the cold side of the generator (usually around $10^{\circ} \mathrm{C}$ [18]), the required mass flow rate of the heating process water is specified:

$$
G_{p w}=\frac{Q_{g(p w)}}{c_{p p w . g . a v}\left(T_{p w w . s g}-\left(T_{4}+10\right)\right)},
$$

where $c_{p}$ pw.g.av - the average heat capacity of the heating process water in the generator, and the calculation according to expressions (1) - (18) is repeated, setting new preliminary values of $G_{p w}$, until the value $G_{p w}$ coincides with that obtained by expression (18).

Further calculated:

- temperature of the liquid phase of the water-ammonia solution in equilibrium with the steam at the beginning of boiling in the generator $T_{1^{\circ}}$, determined by the known values of $P_{c}$ and $\xi_{4}$;

- enthalpy of the liquid phase of the water-ammonia solution in equilibrium with the steam at the beginning of boiling in the generator $i_{1}$, determined by the values of $P_{c}, T_{1}$ and $\xi_{4}$;

- concentration of the solution steam at the generator outlet $\xi_{1}$, determined according to the table of correspondence of the concentration of liquid $\xi_{1^{\circ}}=\xi_{4}$ and the steam phase above the water-ammonia solution [19];

- enthalpy of the solution steam at the outlet of the generator $i_{1^{\prime}}$, determined by the values of $P_{c}, T_{1^{\prime}}=T_{1^{\circ}}$ 。 and $\xi_{1}$;

- temperature $T_{r}=T_{1}$ and enthalpy $i_{r}=i_{1}$ 。 of reflux at the generator inlet;

- temperature of a weak water-ammonia solution at the outlet of the generator:

$T_{2}=T_{p w . s g 2}-\Delta T_{g . h}$

- concentration of a weak water-ammonia solution at the outlet of the generator $\xi_{2}$, determined by the known values of $P_{c}$ and $T_{2}$;

- enthalpy of a weak water-ammonia solution at the outlet of the generator $i_{2}$, determined by the values of $P_{c}, T_{2}$ and $\xi_{2}$;
- frequency of circulation:

$f=\frac{\xi_{e^{\prime}}-\xi_{2}}{\xi_{4}-\xi_{2}}$

- mass flow rate of a strong water-ammonia solution at the generator inlet:

$G_{s . g 1}=f G_{s . c} ;$

- electric power of the strong solution pump:

$N_{p}=\frac{v_{s . p} G_{s . g 1}\left(P_{c}-P_{0}\right)}{\eta_{p} \eta_{m p}}$,

where $v_{s . p}=0.001 /\left(1-0.356 \xi_{4}\right)[15]$ - the specific volume of a strong water-ammonia solution at the inlet of a strong solution pump;

- specific heat load of the absorber:

$q_{a}=i_{8}-i_{2}+f\left(i_{2}-i_{4}\right)$

- heat output of the absorber for the absorption of steam by a weak solution:

$Q_{a(s)}=q_{a} G_{s . c} ;$

- the highest temperature of condensation of the solution steam in the AHP condenser:

$T_{e^{\prime}}=T_{d w . a 1}+\Delta T_{c . h}$

- enthalpy of solution steam at the inlet to the AHP condenser $i_{e^{\prime}}$, determined by the values of $P_{c}, T_{e^{\prime}}$ and $\xi_{e^{\prime}}$; - the mass of reflux in a reflux condenser, referred to $1 \mathrm{~kg}$ of steam:

$R=\frac{\xi_{e^{\prime}}-\xi_{1^{\prime}}}{\xi_{1^{\prime}}-\xi_{4}}$

- specific heat load of the reflux condenser:

$q_{r c}=(1+R) i_{1^{\prime}}-i_{e^{\prime}}-R i_{1^{\circ}} ;$

- specific heat load of the generator:

$q_{g}=i_{e^{\prime}}-i_{2}+f\left(i_{2}-i_{4}\right)+q_{r c}$

- heat output of the reflux condenser for rectification of the steam of the water-ammonia solution:

$Q_{r c}=q_{r c} G_{s . c}$

- mass flow rate of delivery water through a reflux condenser:

$G_{d w . r c}=\frac{Q_{r c}}{i_{d w . a 1}-i_{d w 1}} ;$

- mass flow rate of delivery water through the AHP condenser:

$G_{d w . c}=G_{d w}-G_{d w . r c}$ 
- specific heat load of the AHP condenser:

$q_{c}=i_{e^{\prime}}-i_{6}$

- heating capacity of the AHP condenser for condensation of the steam of the water-ammonia solution:

$$
Q_{c(s)}=q_{c} G_{s . c} .
$$

After this the enthalpy of the delivery water at the inlet to the absorber:

$$
i_{d w . a 1}=i_{d w 1}+\frac{Q_{c(s)}}{G_{d w . c}},
$$

and the corresponding temperature $T_{d x . a 1}$ are specified, and the entire previous calculation according to expressions (1)-(34) is repeated, setting new preliminary values of the parameters of the delivery water at the inlet to the absorber $T_{d w . a 1}, i_{d w . a 1}$, until the value $i_{d w . a 1}$ coincides with the obtained by expression (34).

Then calculated:

- heat output of the generator for evaporation of steam from a strong solution:

$Q_{g(s)}=q_{g} G_{s . c} ;$

- condenser heating capacity for heating delivery water:

$Q_{c(d w)}=G_{d w . . c}\left(i_{d w . a 1}-i_{d w 1}\right)$

- the heating capacity of the absorber for heating delivery water:

$$
Q_{a(d w)}=G_{d w}\left(i_{d w 2}-i_{d w, a 1}\right) .
$$

After this, it is necessary to set a new preliminary value of the electric power generated by the steam turbine plant $N_{e}$. The calculation according to expressions (1)-(37) is repeated with all previous internal iterations (Fig. 2) until the energy balances for all working fluids and heat transfer fluids in all heat exchangers of the system are reached.

Further calculated:

- efficiency of a steam turbine plant:

$$
\eta_{S T P}=\frac{N_{e}}{Q_{s g}+N_{f p}}
$$

- AHP thermal coefficient:

$$
\varsigma_{A H P}=\frac{q_{c-e}}{q_{g}} ;
$$

- AHP transformation coefficient:

$$
\mu_{A H P}=1+\varsigma_{A H P}=\frac{q_{c}+q_{r c}+q_{a}}{q_{g}} .
$$

The exergy analysis method [20-22] provides an opportunity to identify the nature of external and internal losses both in cycles in general and in individual elements of the considered cogeneration system, and to outline ways to improve its scheme and design.
Therefore, to analyze the thermodynamic perfection of the system, in each element the exergy flows $E_{i}$ and its losses due to the irreversibility $E_{D i}$, the exergy efficiency of the elements $\eta_{e i}$ and the whole system $\eta_{e}$ are calculated For this, the values of the entropy of the energy carriers at the input and output of each element $s_{i}$ are determined, and the value of the ambient temperature $T_{a m}$, which plays the role of the exergy reference level, is set.

The internal exergy losses from irreversibility (nonisentropicity) expansion in the turbine were calculated by the formula:

$$
E_{D w . t}=G_{w} T_{a m}\left(s_{w . t 2}-s_{w . t 1}\right) .
$$

Mechanical losses in the bearings of the turbine shaft are determined as:

$$
E_{D f r . t}=N_{e} \frac{1-\eta_{m . t}}{\eta_{e m . t}}
$$

where $\eta_{m . t}$ - the mechanical efficiency of the turbine.

Electromagnetic losses in the electric generator are found from the expression:

$$
E_{\text {Dem.t }}=N_{e}\left(\frac{\eta_{m . t}}{\eta_{e m . t}}-1\right) .
$$

The total exergy losses in the turbine-electric generating unit are determined by summing of expressions (41)-(43):

$$
E_{D t}=E_{D w . t}+E_{D f r . t}+E_{\text {Dem.t. }} .
$$

In the steam generator, condenser-evaporator and AHP condenser enter and exit, without touching, two flows of heat transfer fluids. Therefore, the change in exergy of the $j$-th heat transfer fluid in the $i$-th element is calculated by the expression:

$$
\Delta E_{j . i}=G_{j . i}\left[i_{j . i 1}-i_{j . i 2}-T_{a m}\left(s_{j . i 1}-s_{j . i 2}\right)\right] .
$$

In the generator, reflux condenser and absorber, more than one stream of different phases of the water-ammonia solution enter and exit, which are in contact with each other. Therefore, the change in the exergy of the waterammonia solution in these elements is determined as:

$$
\Delta E_{s . i}=\sum E_{s . i 1}-\sum E_{s . i 2},
$$

where $\Sigma E_{s . i 1}$ and $\Sigma E_{s . i 2}$ - the total exergy of different phases of the water-ammonia solution at the input and output of the $i$-th element.

The exergy of the different phases of the water-ammonia solution in the $i$-th element is calculated by the expression:

$$
E_{s . i}=G_{s . i}\left[i_{s . i}-i_{s . a m}-T_{a m}\left(s_{s . i}-s_{s . a m}\right)\right]
$$

where $i_{\text {s.am }}$ and $s_{\text {s.am }}$ - the enthalpy and entropy of the waterammonia solution, respectively, at environmental parameters.

The change in the exergy of the heating process water and delivery water in the generator, reflux condenser, and absorber are determined by expression (45).

Losses of exergy in the heat exchangers of the system are determined as:

$$
E_{D i}=\Delta E_{(1) i}-\Delta E_{(2) i},
$$


where $\Delta E_{(1) i}$ and $\Delta E_{(2) i}$ - the changes in the exergy of the first and second heat carriers when passing through the element, calculated by expressions (45) and (46).

The internal exergy losses during the throttling of the water-ammonia solution in THR-1 and THR-2 are calculated by the formula:

$$
E_{D t h r-i}=G_{s . t h r-i} T_{a m}\left(s_{s . t h r-i 2}-s_{s . t h r-i 1}\right) .
$$

The exergy efficiency of the turbine-electric generating unit is calculated from the expression:

$$
\eta_{e . t}=\frac{N_{e}}{\Delta E_{w . t}+E_{D f r . t}+E_{\text {Dem.t }}},
$$

where $\Delta E_{\tau, t}$ - the change in the exergy of water steam in the turbine, calculated by the expression (45).

The exergy efficiency of the heat exchangers of the system is defined as the ratio of the changes in the exergy of the heat carriers flows in them, calculated by the expressions (45) and (46):

$$
\eta_{e i}=\frac{\Delta E_{(1) i}}{\Delta E_{(2) i}} .
$$

The total exergy at the inlet to the cogeneration heat recovery system $\Sigma E_{C S 1}$ is calculated by adding the exergy of the heating process water at the inlet to the steam generator $E_{\text {pw.sg } 1}$ and the exergy of the reverse delivery water at the entrance to the AHP $E_{d w . A H P 1}$. The total exergy at the exit from the system $\Sigma E_{C S 2}$ is determined by adding the exergy of the heating process water at the outlet of the generator $E_{\text {pw.g2 }}$, the exergy of direct delivery water at the outlet of the AHP absorber $E_{d w . A H P 2}$ and the electric power generated by the steam turbine plant $N_{e}$. The values $E_{p w . s g 1}, E_{d w . A H P 1}, E_{p w . g 2}$ and $E_{d w . A H P 2}$ are calculated for water by an expression similar to (47).

The exergy efficiency of the cogeneration heat recovery system is calculated according to the dependence [22]:

$$
\eta_{e}=\frac{\sum E_{C S 2}}{\sum E_{C S 1}} .
$$

The constructed software package for calculating the thermodynamic and exergy characteristics of the cogeneration heat recovery system is used in numerical studies of its energy efficiency indicators to find ways to increase the degree of its thermodynamic perfection.

\section{Research results}

Based on a numerical experiment, the analysis of energy and exergy indicators of a cogeneration heat recovery system with a variation of 4 factors:

1) condensation temperature of the spent water steam in the condenser-evaporator $T_{\text {C.STP }}$;

2) temperature of the heating process water at the inlet to the STP steam generator $T_{\text {press } 1 \text {; }}$

3) temperature of the reverse delivery water at the inlet to the AHP $T_{d w 1}$;

4) mass flow rate of heated delivery water $G_{d w}$.

For this, a 4-block centroid plan for varying these $4 \mathrm{fac}-$ tors is compiled. $T_{\text {C.STP }}$ value ranges from $30{ }^{\circ} \mathrm{C}$ to $45^{\circ} \mathrm{C}$,
$T_{\text {pw.sg } 1}$ - from $175{ }^{\circ} \mathrm{C}$ to $215{ }^{\circ} \mathrm{C}, T_{d w 1}-$ from $30{ }^{\circ} \mathrm{C}$ to $40{ }^{\circ} \mathrm{C}$ and $G_{d w}-$ from $73 \mathrm{~kg} / \mathrm{s}$ to $113 \mathrm{~kg} / \mathrm{s}$.

There are unchanged source data:

- temperature of direct delivery water at the outlet of AHP $T_{d w 2}=90{ }^{\circ} \mathrm{C}$;

- water steam temperature at the turbine inlet $T_{\text {w.t } 1}=$ $=100{ }^{\circ} \mathrm{C}$;

- temperature differences of the heat transfer fluids on the cold and hot sides of the AHP condenser, respectively, $\Delta T_{c . c}=10{ }^{\circ} \mathrm{C}$ and $\Delta T_{c . h}=5{ }^{\circ} \mathrm{C}$;

- temperature differences of the heat transfer fluids on the cold and hot sides of the condenser-evaporator, respectively, $\Delta T_{c-e . c}=15{ }^{\circ} \mathrm{C}$ and $\Delta T_{c-e . h}=5{ }^{\circ} \mathrm{C}$;

- temperature difference of the heat transfer fluids on the cold side of the absorber $\Delta T_{a . c}=5{ }^{\circ} \mathrm{C}$ and the hot side of the generator $\Delta T_{g . h}=4^{\circ} \mathrm{C}$;

- concentration of the purified steam of the solution at the outlet of the reflux condenser $\xi_{e^{\prime}}=0.9995 \mathrm{~kg} / \mathrm{kg}$; - concentration of saturated steam of the solution at the end of the boiling process in the condenser-evaporator $\xi_{8^{\prime}}=0.9999 \mathrm{~kg} / \mathrm{kg}$;

- internal relative $\eta_{\text {in.t }}=0.85$, mechanical $\eta_{\text {m.t }}=0.97$ and electromechanical $\eta_{e m . t}=0.96$ efficiency of the STP turbine-electric generating unit;

- efficiency of the pumps $\eta_{f p}=\eta_{p}=0.88$ and their electric motors $\eta_{m f p}=\eta_{m p}=0.85$.

Some calculation results are presented in Fig. 3-10, where the influence of variable factors $T_{c . S T P}, T_{p w . s g 1}, T_{d w 1}$ and $G_{d w}$ on the thermodynamic and exergy characteristics of the cogeneration heat recovery system under consideration is shown.
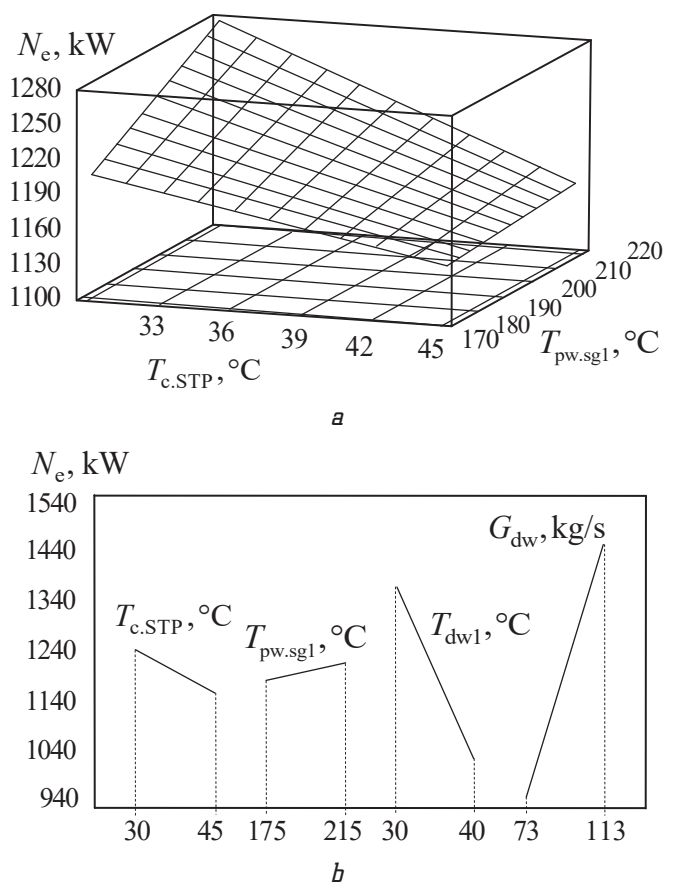

Fig. 3. The electric power of the steam turbine plant $N_{\varepsilon}$ : $a$ - when variation of $T_{c . S T P}$ and $T_{p w . S g}$ i; $b$ - when changing $T_{c .5 T P}, T_{p w . s g 1}, T_{d w 1}$ and $G_{d w}$

From Fig. 3 it can be seen, for example, that with a decrease in the condensation temperature of the spent water steam in the steam turbine plant $T_{C . S T P}$ due to the improvement of the vacuum in the condenser-evaporator and increase in the triggered heat drop in the steam turbine, 
the generation of electricity increases and the efficiency of the STP increases. However, this reduces the transformation coefficient of the absorption heat pump at the same heat output (Fig. 4).
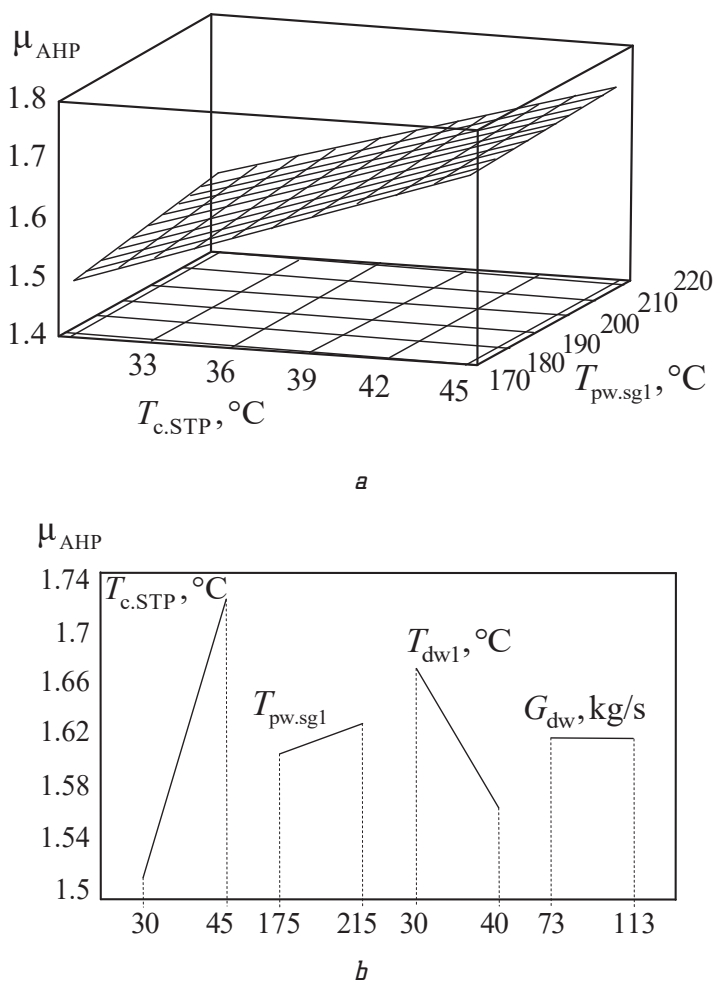

Fig. 4. Transformation coefficient of the absorption heat pump $\mu_{A H P}$ : $a$ - when variation of $T_{C . S T P}$ and $T_{P W S G 1}$. $b$ - when changing $T_{c .5 T P}, T_{p w . s g 1}, T_{d w 1}$ and $G_{d w}$

There is a redistribution of the heating load from the heat pump condenser (Fig. 5) to the absorber (Fig. 6) and the reflux condenser. The exergy efficiency of these heat exchangers is much lower than that of a heat pump condenser. This is due to the presence of losses from the irreversibility of mass transfer processes during rectification and the incompleteness of the process of steam absorption in the absorber due to the finite contact time of the steam and the solution.

The nature of the change in the values of the heat output of the generator (Fig. 7) is similar to the nature of the change in the heat output of the absorber (Fig. 6).

The values $Q_{g}$ and $Q_{a}$ increase only with an increase in the mass flow rate of delivery water $G_{d w}$ due to an increase in the overall system capacity. With increasing values of temperatures of the spent water steam condensation $T_{\text {c.STP }}$, the heating process water $T_{p w . s g 1}$ and the reverse delivery water $T_{d w 1}$, the values $Q_{g}$ and $Q_{a}$ decrease. This is due to a concomitant increase in the heat output of the steam generator, condenser-evaporator and heat pump condenser (Fig. 5) due to the redistribution of the temperature potentials of the heat flows in the system.

A change in the values of the exergy efficiency of the cogeneration system with a variation of $T_{c . S T P}$ and $T_{p w .1}$, as well as with a change in the values of $T_{c . S T P}, T_{p w . s g 1}, T_{d w 1}$ and $G_{d w}$ are shown in Fig. 8. Fig. 8 shows that the exergy efficiency of the cogeneration system $\eta_{e}$ increases with increasing temperature of the reverse delivery water $T_{d w 1}$ at the inlet to the heat pump and decreases with increasing temperatures of the spent water steam condensation $T_{\text {C.STP }}$

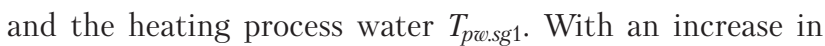
the mass flow rate of delivery water $G_{d w}$, the value $\eta_{e}$ remains unchanged. Since an increase in $G_{d w}$ with a constant value of the other three variable factors does not lead to a change in the thermodynamic parameters of the system cycles, but only to an increase in its overall performance.
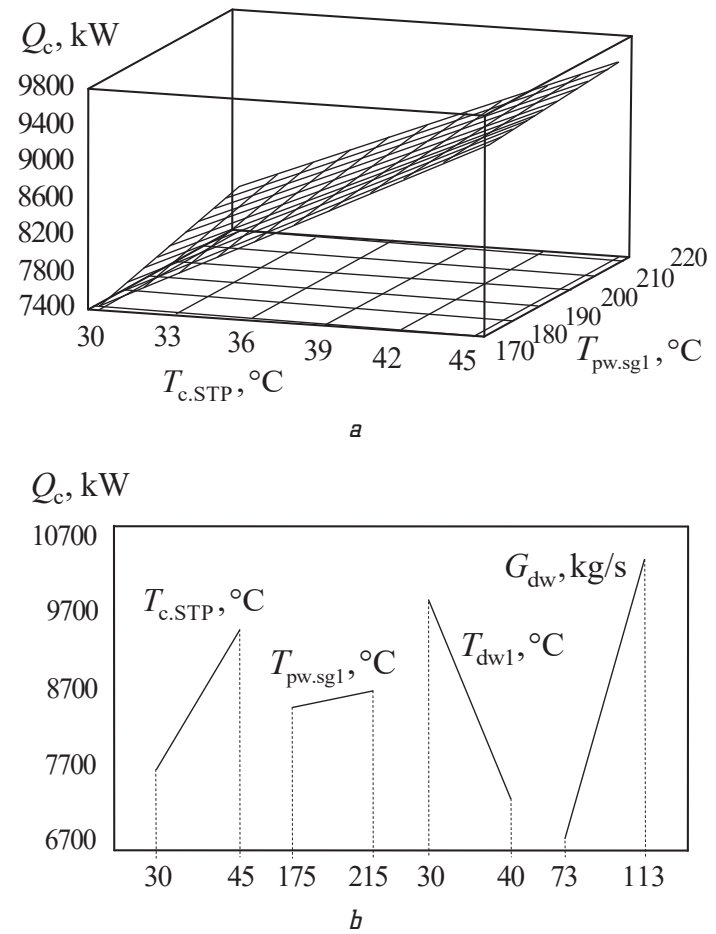

Fig. 5. Heat output of the heat pump condenser $\square_{C}$ :

a - when variation of $T_{c .5 T P}$ and $T_{p w . S g}$;

$b$ - when changing $T_{c .5 T P,} T_{p w . s g 1}, T_{d w 1}$ and $G_{d w}$

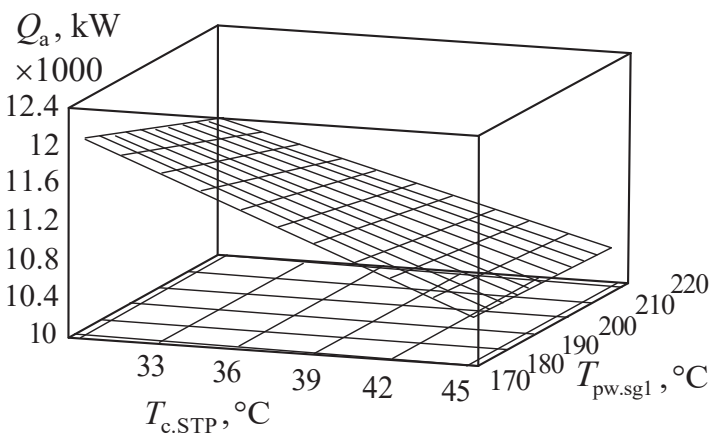

a

$Q_{\mathrm{a}}, \mathrm{kW}$

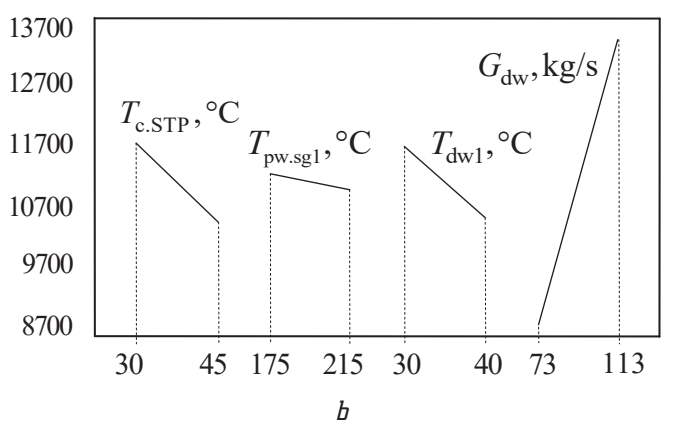

Fig. 6. Heat output of the absorber $\square_{a}$ :

$a$ - when variation of $T_{c . S T P}$ and $T_{\text {PW.Sgli }}$;

$b$ - when changing $T_{c . S T P}, T_{p w . s q 1}, T_{d w 1}$ and $G_{d w}$ 


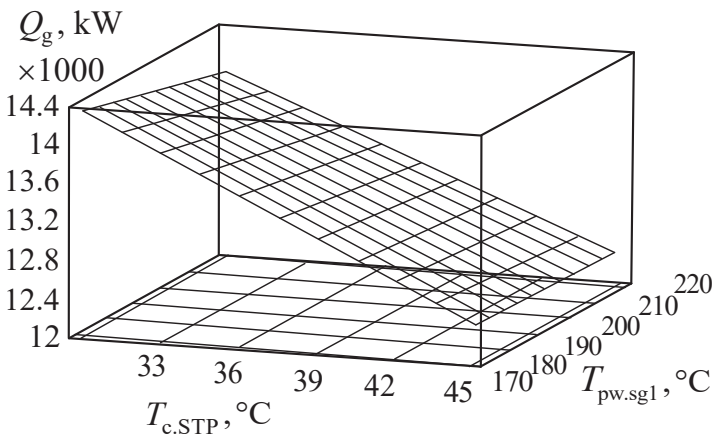

$a$

$Q_{\mathrm{g}}, \mathrm{kW} \times 1000$

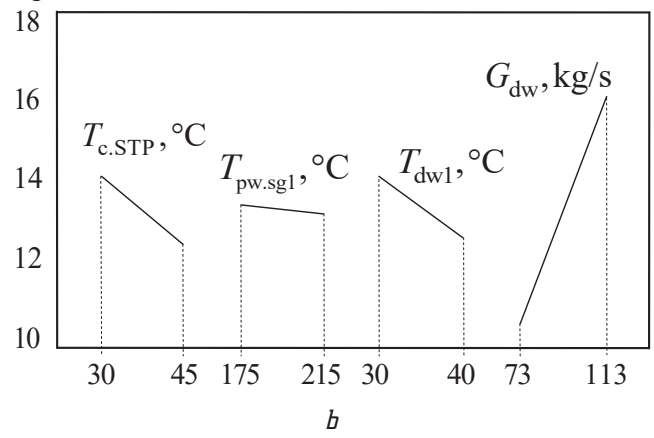

Fig. 7. Heat output of the generator $\square_{g}$ :

$a$ - when variation of $T_{c . S T P}$ and $T_{p w . s g}{ }$ $b$ - when changing $T_{c . S T P}, T_{p w . s g 1}, T_{d w 1}$ and $G_{d w}$

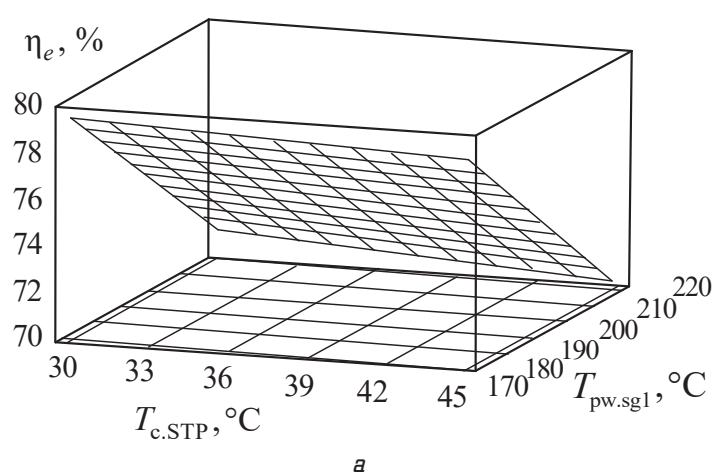

$\eta_{e}, \%$

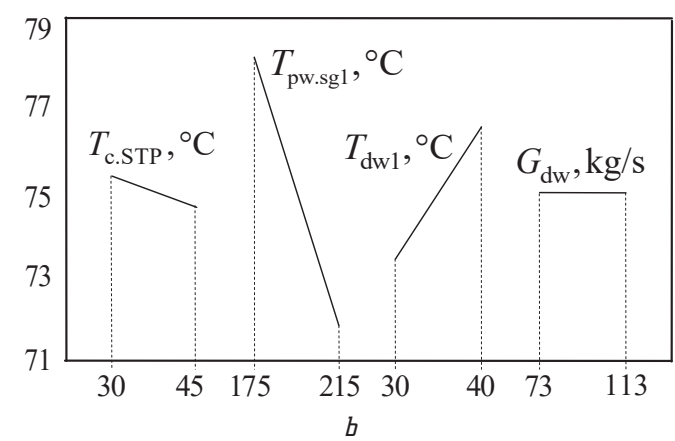

Fig. 8. The exergy efficiency of the cogeneration system $\eta_{e}$ $a$ - when variation of $T_{\text {c.STP }}$ and $T_{p w . s g 1}$; $b$ - when changing $T_{c .5 T P}, T_{p w . s g 1}, T_{d w 1}$ and $G_{d w}$

Moreover, the nature of the change in the values of the exergy efficiency of the cogeneration system $\eta_{e}$ under the mutual influence of $T_{C . S T P}, T_{p w . s g 1}, T_{d w 1}$ and $G_{d w}$ (Fig. 9) is opposite to the nature of the change in the transformation coefficient of the absorption heat pump $\mu_{A H P}$ (Fig. 10). $\eta_{e}, \%$

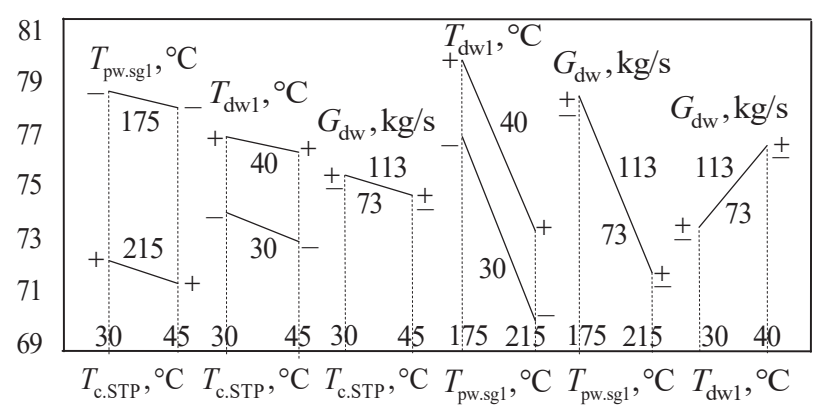

Fig. 9. The exergy efficiency of the cogeneration system $\eta_{e}$ under the mutual influence of $T_{c . S T P}, T_{p w . S g 1}, T_{d w 1}$ and $G_{d w}$

$\mu_{\mathrm{AHP}}$

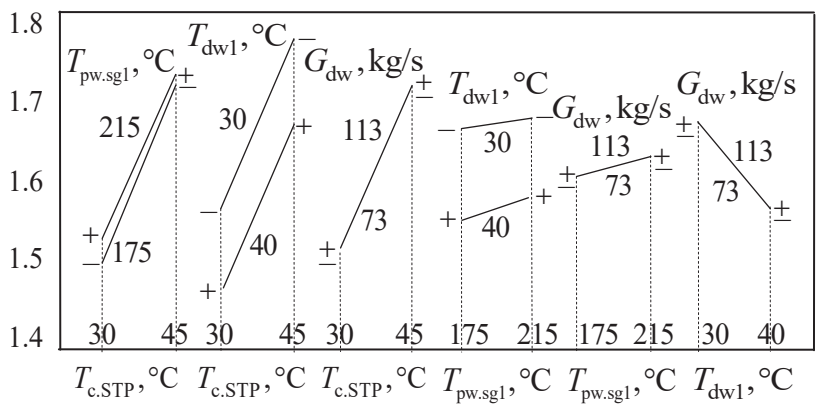

Fig. 10. Transformation coefficient of the absorption heat pump $\mu_{A H P}$ under the mutual influence of $T_{c .5 T P,}, T_{p w . s g 1}, T_{d w 1}$ and $G_{d w}$

From Fig. 9, 10 it can be seen, for example, that with an increase in $T_{C . S T P}$, the AHP transformation coefficient increases, and the exergy efficiency of the entire system decreases due to a decrease in the triggered heat drop in the steam turbine and a decrease in the efficiency of the STP. Moreover, the lower the temperature $T_{d w o 1}$, the higher $\mu_{A H P}$ and the lower $\eta_{e}$. With an increase in temperature $T_{\text {pซossg } 1}$, the AHP transformation coefficient slightly increases, however, the exergy efficiency of the entire system decreases significantly due to a considerable increase in the temperature difference of the heat transfer fluids on the hot side of the absorber. This leads to an increase in losses from external irreversibility.

From an energy point of view, in order to reduce external irreversibility, it is advisable to strive for an extremely small value of the temperature difference between the heat transfer fluids in heat exchangers. However, in practice, this requirement often leads to an increase in the heat exchange surface and, accordingly, to an increase in the cost of the unit.

Despite the high energy efficiency of cogeneration heat recovery systems built using energy-saving heat pump technology, their widespread adoption in industry is constrained by the rather high initial costs of their acquisition and installation. It is necessary to search for compromise solutions that allow, without departing significantly from the reversible flow of processes, to obtain a relatively compact, less metal-intensive and cheap design.

This problem can be solved using the thermoeconomic method [23-25], which organically combines economic and thermodynamic indicators, and thereby makes it possible to solve optimization problems by means of exergy technical and economic optimization. At the same time, internal energy processes in the system are optimized in order 
to increase the degree of its thermodynamic perfection and reduce the level of resulting costs for its creation and operation.

The presence in the composition of the cogeneration heat recovery system of the absorption heat pump determines the occurrence of several complex interconnected thermodynamic and mass transfer processes in it. Therefore, it is advisable to solve the issues of exergy-economic optimization of the system under consideration using the structural-variant method [25-27] based on the use of structural linkage coefficients, with the help of which each element can be considered in isolation from the system.

In this regard, a generalized regression equation of the functional relationship of the exergy efficiency of the elements of the system and the entire system as a whole has been obtained:

$$
\begin{aligned}
& \eta_{e}=21.6061878204346-0.395117491483688 \eta_{e . t}+ \\
& +0.865216732025146 \eta_{e . s g}-0.387229800224304 \eta_{e . c-e}+ \\
& +0.116352297365665 \eta_{e . g}+0.316142529249191 \eta_{e . r c}+ \\
& +0.0221583619713783 \eta_{e . c}+0.36931511759758 \eta_{e . a} .
\end{aligned}
$$

Table 1 shows the impact coefficients of exergy efficiency of elements on the thermodynamic perfection of the entire system.

Impact coefficients of exergy efficiency of elements on the thermodynamic perfection of the entire system

\begin{tabular}{|l|c|}
\hline \multicolumn{1}{|c|}{ Factor } & Impact coefficient \\
\hline $\begin{array}{l}\text { Exergy efficiency of the turbine-electric generating } \\
\text { unit } \eta_{e . t}\end{array}$ & 0.7669578 \\
\hline Exergy efficiency of the steam generator $\eta_{e . s g}$ & 0.8900728 \\
\hline Exergy efficiency of the condenser-evaporator $\eta_{e . c-e}$ & 0.2882579 \\
\hline Exergy efficiency of the generator $\eta_{e . g}$ & 0.7855726 \\
\hline Exergy efficiency of the reflux condenser $\eta_{e . r c}$ & 0.6868756 \\
\hline Exergy efficiency of the AHP condenser $\eta_{e . c}$ & 0.8062127 \\
\hline Exergy efficiency of the absorber $\eta_{e . a}$ & 0.3794129 \\
\hline
\end{tabular}

Data in Table 1 shows that the most influential elements during the subsequent exergy-economic optimization will be the steam generator of the steam turbine plant and the heat pump condenser, and the least - the condenser-evaporator and absorber.

As can be seen from the calculation results, this cogeneration system provides heat recovery with rather low losses in the entire considered range of change of varied parameters. This high efficiency is determined by the fact that the low-grade heat of condensation of the spent water steam in the condenser-evaporator is converted into heat suitable for practical purposes - heating and hot water supply.

\section{SWOT analysis of research results}

Strengths. Thanks to the method of exergy analysis used in the research, it is possible to identify the nature of external and internal losses both in cycles in general and in individual elements of the considered cogeneration system, which can't be taken into account by standard engineering methods. This allows to identify ways to improve the scheme and design of the system in order to reduce the resulting costs for its creation and operation.

Weaknesses. The disadvantages of the constructed software package for calculating the thermodynamic and exergy characteristics of the cogeneration system include the fact that to simplify the calculations, the resistance in the connecting pipelines was not taken into account. Therefore, the pressure in the generator and the reflux condenser is taken equal to the pressure in the AHP condenser, and the pressure in the absorber is taken equal to the boiling pressure in the condenser-evaporator. This, as well as not taking into account the incompleteness of the boiling, rectification and absorption processes, and heat losses from external cooling, reduces the accuracy of calculating the energy characteristics of the system. However, due to the presence of several interconnected heat exchangers in the object under consideration and the complexity of the thermodynamic and mass transfer processes occurring in them, the adoption of such simplifications at this stage of the research reduces the complexity of the calculations.

Opportunities. Promising research should include solving the problem of optimal design of the cogeneration system under consideration, taking into account its economic, environmental and energy indicators. In this case, it is advisable to include in the software package for calculating the corresponding equations to account for hydraulic losses in the connecting pipelines of the system, the incompleteness of the boiling, rectification and absorption processes, heat losses from external cooling. This together reduces the energy performance of the system.

Threats. Despite the high energy efficiency of cogeneration heat recovery systems built using energy-saving heat pump technology, potential buyers and investors are constrained by the relatively high initial costs of their acquisition and installation. At the same time, the payback period of such systems substantially depends on the availability of stable consumers of the heat and electricity generated by them.

\section{Conclusions}

1. On the basis of mathematical modeling of heat and mass transfer processes for the cogeneration system under consideration, a software package for calculating its thermodynamic and exergy characteristics is built with the aim of conducting numerical studies of its energy efficiency indicators. To identify the parameters of the state of the working fluid at the nodal points of the cycles of the absorption heat pump, a database has been obtained for calculating the thermophysical properties of the water-ammonia solution taking into account changes in its concentration.

2. As a result of a numerical experiment, the influence of 4 factors on the operation modes of the cogeneration system is investigated. These 4 factors are:

- condensation temperature of spent water steam in

a steam turbine plant $T_{\text {C.STP }}$;

- temperature of heating process water at the inlet to the steam generator of the steam turbine plant $T_{\text {pre.sg } 1}$; - temperature of the reverse delivery water at the inlet to the heat pump $T_{d w 1}$;

- mass flow rate of delivery water $G_{d w}$. 
It is established that the nature of the change in the values of the exergy efficiency of the cogeneration system under the mutual influence of the variable factors $T_{c . S T P}, T_{p w . s g 1}, T_{d w 1}$ and $G_{d w}$ is opposite to the nature of the change in the transformation coefficient of the absorption heat pump.

3. A generalized regression equation of the functional relationship of the exergy efficiency of the elements of the cogeneration system and the entire system as a whole has been obtained. The impact coefficients of exergy efficiency of elements on the thermodynamic perfection of the entire system are analyzed. The most influential elements during subsequent optimization will be the steam generator of the steam turbine plant and the heat pump condenser, and the least - the condenser-evaporator and absorber.

\section{References}

1. Psakhis, B. I. (1984). Metody ekonomii sbrosnogo tepla. Novosibirsk: Zapadno-Sibirskoe knizhnoe izdatelstvo, 160.

2. Orekhov, I. I., Timofeevskii, L. S., Karavan, S. V. (1989). Absorbcionnye preobrazovateli teploty. Leningrad: Khimiia, 207.

3. Galimova, L. V. (1997). Absorbcionnye kholodilnye mashiny i teplooye nasosy. Astrakhan: AGTU, 226.

4. Shubenko, A. L., Babak, N. U., Seneckiy, A. V., Malyarenko, V. A. (2012). Utilization of waste warmth of technological processes of the industrial enterprise for the purpose of electric power development. Energosberezhenie. Energetika. Energoaudit, 7 (101), 23-29.

5. Peris, B., Navarro-Esbrí, J., Molés, F., Mota-Babiloni, A. (2015). Experimental study of an ORC (organic Rankine cycle) for low grade waste heat recovery in a ceramic industry. Energy, 85, 534-542. doi: http://doi.org/10.1016/j.energy.2015.03.065

6. Van de Bor, D. M., Infante Ferreira, C. A., Kiss, A. A. (2015) Low grade waste heat recovery using heat pumps and power cycles. Energy, 89, 864-873. doi: http://doi.org/10.1016/ j.energy.2015.06.030

7. Vedil, S. N., Kumar, A., Mahto, D. (2014). Waste heat Utilization of vapour compression cycle. International Journal of Scientific and Research Publications, 4 (1), 444-450. doi: http:// doi.org/10.23883/ijrter.2018.4376.dmnam

8. Singh, S., Dasgupta, M. S. (2017) $\mathrm{CO}_{2}$ heat pump for waste heat recovery and utilization in dairy industry with ammonia based refrigeration. International Journal of Refrigeration, 78, 108-120. doi: http://doi.org/10.1016/j.ijrefrig.2017.03.009

9. Zhang, G., Li, Sh., Jiang, H., Xie, G. (2015). Application of Radial Heat Pipe to Heat Recovery of Flue Gas. Proceedings of 5th International Conference on Advanced Engineering $\mathrm{Ma}$ terials and Technology, 282-285. doi: http://doi.org/10.2991/ icaemt-15.2015.56

10. Remeli, M. F., Kiatbodin, L., Singh, B., Verojporn, K., Date, A., Akbarzadeh, A. (2015). Power Generation from Waste Heat Using Heat Pipe and Thermoelectric Generator. Energy Procedia, 75, 645-650. doi: http://doi.org/10.1016/j.egypro.2015.07.477

11. Utlu, Z., Önal, B. S. (2018). Thermodynamic analysis of thermophotovoltaic systems used in waste heat recovery systems: an application. International Journal of Low-Carbon Technologies, 13 (1), 52-60. doi: http://doi.org/10.1093/ijlct/ctx019

12. Oin, P., Chen, H., Chen, L., Wang, C., Liu, X. Hu, X et. al. (2013). Analysis of recoverable waste heat of circulating cooling water in hot-stamping power system. Clean Technologies and Environmental Policy, 15 (4), 741-746. doi: http://doi.org/ 10.1007/s10098-012-0557-3
13. Chepurnoi, M. N., Rezident, N. V. (2013). Primenenie parokompressionnykh teplonasosnykh ustanovok dlia utilizacii sbrosnoi teploty kondensatorov parovykh turbin. Naukovi praci VNTU, 4, $1-7$.

14. Kostiuk, A. G., Frolov, V. V., Bulkin, A. E., Trukhnii, A. D (2001). Turbiny teplovykh $i$ atomnykh elektricheskikh stancii. Moscow: Izdatelstvo MEI, 488.

15. Stoletov, V. M. (2007). Teoreticheskie osnovy kholodilnoi tekhniki. Kemerovo: KTIPP, 88.

16. Timofeevskii, L. S. (1997). Kholodilnye mashiny. Saint Petersburg: Politehnika, 992.

17. Bogdanov, S. N., Burcev, S. I., Ivanov, O. P., Kupriianova, A. V (1999). Kholodilnaia tekhnika. Kondicionirovanie vozdukha. Svoistva veschesto. Saint Petersburg: SPbGAKHPT, 320.

18. Sakun, I. A. (1987). Teplovye $i$ konstruktivnye raschety kholodilnykh mashin. Leningrad: Mashinostroenie, 423.

19. Komarov, N. S. (1953). Spravochnik kholodilschika. Kyiv: Gosudarstvennoe izdatelstvo tekhnicheskoi literatury USSR, 396.

20. Brodianskii, V. M. (1988). Eksergeticheskii metod i perspektivy ego razvitiia. Teploenergetika, 2, 14-17.

21. Morosuk, T., Tsatsaronis, G. (2008). A new approach to the exergy analysis of absorption refrigeration machines. Energy, 33 (6), 890-907. doi: http://doi.org/10.1016/j.energy.2007.09.012

22. Morosuk, L. I., Grudka, B. G. (2017). Introduction to the Exergy Analysis of Absorption-Resorption Refrigeration Machine. Refrigeration Engineering and Technology, 53 (1), 4-10 doi: http://doi.org/10.15673/ret.v53i1.533

23. Kuznecov, M. A. (2012). Termoekonomicheskii analiz teplonasosnoi sushilnoi ustanovki. Problemy mashinostroeniia, 15 (1), $36-42$.

24. Kuznetsov, M., Kharlampidi, D., Tarasova, V., Voytenko, E. (2016). Thermoeconomic optimization of supercritical refrigeration system with the refrigerant R744 $\left(\mathrm{CO}_{2}\right)$. Eastern-European Journal of Enterprise Technologies, 6 (8 (84)), 24-32. doi: http:// doi.org/10.15587/1729-4061.2016.85397

25. Kharlampidi, D. Kh., Tarasova, V. A., Kuznetsov, M. A. (2015) Advanced techniques of thermodynamic analysis and optimization of refrigeration units. Industrial Gases, 6, 55-64. doi: http:// doi.org/10.18198/j.ind.gases.2015.0802

26. Macevitii, Iu. M., Kharlampidi, D. Kh., Tarasova, V. A., Kuznecov, M. A. (2016). Termoekonomicheskaia diagnostika $i$ optimizaciia parokompressornykh termotransformatorov. Kharkiv: ChP «Tekhnologicheskii Centr», 160.

27. Kharlampidi, D., Tarasova, V., Kuznetsov, M., Voytenko, E. (2017). Thermodynamic analysis of air-compression refrigerating machine based on the exergy cost theory. Eastern-European Journal of Enterprise Technologies, 5 (8 (89)), 30-38. doi: http:// doi.org/10.15587/1729-4061.2017.112113

Kuznetsov Mikhail, PhD, Researcher, Department of Thermal Process Modeling and Identification, A. Podgorny Institute of $\mathrm{Me}$ chanical Engineering Problems of the National Academy of Sciences of Ukraine, Kharkiv, Ukraine, e-mail: childeric1975@gmail.com, ORCID: http://orcid.org/0000-0002-5180-8830

Kharlampidi Dionis, Doctor of Technical Sciences, Leading Researcher, Department of Thermal Process Modeling and Identification, A. Podgorny Institute of Mechanical Engineering Problems of the National Academy of Sciences of Ukraine, Kharkiv, Ukraine, e-mail: kharlampidi@ipmach.kharkov.ua, ORCID: http://orcid.org/ 0000-0003-4337-6238

Tarasova Victoria, PhD, Senior Researcher, Department of Thermal Process Modeling and Identification, A. Podgorny Institute of Mechanical Engineering Problems of the National Academy of Sciences of Ukraine, Kharkiv, Ukraine, e-mail: vat523710@gmail.com, ORCID: http://orcid.org/0000-0003-3252-7619 